\title{
Effect of Planting Pattern and Weeding Frequency on Weed Infestation, Yield Components and Yield of Cowpea [Vigna unguiculata (L.) WALP.] in Wollo, Northern Ethiopia
}

\author{
Getachew Mekonnen ${ }^{1, ~}$, J. J. Sharma ${ }^{2}$, Lisanework Negatu ${ }^{2}$, Tamado Tana ${ }^{2}$ \\ ${ }^{1}$ College of Agriculture and Natural Resources, Mizan Tepi University, Mizan Teferi, Ethiopia \\ ${ }^{2}$ College of Agriculture and Environmental Sciences, Haramaya University, Dire Dawa, Ethiopia
}

Email address:

sibuhmekdes@gmail.com (G. Mekonnen)

${ }^{*}$ Corresponding author

To cite this article:

Getachew Mekonnen, J. J. Sharma, Lisanework Negatu, Tamado Tana. Effect of Planting Pattern and Weeding Frequency on Weed Infestation, Yield Components and Yield of Cowpea [Vigna unguiculata (L.) WALP.] in Wollo, Northern Ethiopia. Agriculture, Forestry and Fisheries. Vol. 6, No. 4, 2017, pp. 111-122. doi: 10.11648/j.aff.20170604.12

Received: January 16, 2017; Accepted: March 13, 2017; Published: July 10, 2017

\begin{abstract}
Weed competition is one of the most important production constraints causing up to $91.6 \%$ reduction in potential yield of cowpea. Therefore, an experiment was conducted at Sirinka and at Jari, northern Ethiopia, during the 2014 main cropping season: to evaluate the effect of planting pattern and frequency of weeding on weeds, yield components and yield of cowpea. There were 18 treatments comprising combination of three planting patterns $(\mathrm{S} 1: 60 \mathrm{~cm} \times 10 \mathrm{~cm}, \mathrm{~S} 2: 45 \mathrm{~cm} \times 15 \mathrm{~cm}$, S3: $45 \mathrm{~cm} \mathrm{x} 10 \mathrm{~cm}$ ) and six weeding frequencies viz. one hand weeding and hoeing at 2 weeks after crop emergence (WAE), one hand weeding and hoeing at $3 \mathrm{WAE}$, one hand weeding and hoeing at $4 \mathrm{WAE}$, two hand weeding and hoeing at 2 and 5 WAE, weed free check, and weedy check. The treatments were arranged in factorial combination in a randomized complete block design with three replications. Results showed significantly lower total weed dry weight at Sirinka than at Jari. The highest weed control efficacy was recorded in two hand weeding and hoeing at 2 and 5 WAE of cowpea at Sirinka. The plants in weedy check plots at Jari attained maximum height which was significantly higher than all the other treatments. Significantly highest number of pods per plant was recorded in weed free check under $60 \mathrm{~cm}$ x $10 \mathrm{~cm}$ spacing at Jari. Number of seeds per pod was highest in weed free check at $45 \mathrm{~cm}$ x $10 \mathrm{~cm}$ spacing at Sirinka. The interaction of weeding frequency and location had significant effect on cowpea dry biomass yield. The highest total dry biomass $\left(12413 \mathrm{~kg} \mathrm{ha}^{-1}\right)$ was obtained in one hand weeding and hoeing at 4 WAE at Jari while the highest grain yield $\left(4508 \mathrm{~kg} \mathrm{ha}^{-1}\right)$ was recorded from complete weed free under $60 \mathrm{~cm} \times 10 \mathrm{~cm}$ spacing at Sirinka. The harvest index ranged from $18.2 \%$ in weedy check at Jari to $39.1 \%$ in weed free check at Sirinka. The results indicated that the use of $60 \mathrm{~cm} \times 10 \mathrm{~cm}$ planting pattern in combination with hand weeding and hoeing at $3 \mathrm{WAE}$ at Sirinka and hand weeding and hoeing at $4 \mathrm{WAE}$ at Jari proved to be the most feasible practice.
\end{abstract}

Keywords: Broadleaved, Grain Yield, Weed Control Efficiency, Weed Density, Weed Dry Weight

\section{Introduction}

Cowpea [Vigna unguiculata (L.) Walp.] is one of the most important food and forage legumes in the semi-arid tropics that include parts of Africa, Asia, Central and South America, Southern Europe, and Southern United States [1]. Both grain and leaves are edible products of cowpea that are rich and cheap sources of high quality protein. They supplement to the lower quality cereal or root and tuber protein commonly consumed in tropical Africa [2]. In addition to its contribution to nutrition and food security, cowpea is also major sources of income for smallholder farmers especially women [3]. Cowpea fixes atmospheric nitrogen through symbiosis with nodule bacteria [4]. It does well and is most popular in the semi-arid tropics where other food legumes do not perform well [5]. Thus it is an extremely resilient crop to moisture stress and cultivated under some of the most extreme agricultural conditions in the world [6].

The need to provide food in the right quantity and quality and at affordable price remains a priority in most of the 
developing countries, where the bulk of agricultural production is largely in the hands of peasant farmers. Constraints faced by this category of farmers include the use of poor plant genetic materials and inadequate crop agronomic practices [7].

Weeds are a permanent constraint to crop productivity in agriculture and compete for nutrients, space, light and exert lot of harmful effects by reducing the quality as well as quantity of the crop, if the weed populations are left uncontrolled [8]. There are different views about the magnitude of yield losses due to weeds, but it is an established fact that weeds cause heavy losses to crops. One of the components of improved production technology is appropriate weed control, because weeds are of serious concern for obtaining higher yield [9]. Cowpea yield loss due to weed interference was described up to $96 \%$, which indicates the importance of weed management in this crop [10]. However the reduction in yield of cowpea depends on the weed species, weed density and weed dry biomass [11].

To fully exploit the potential of improved varieties and available natural and environmental resources, optimum agronomic practices like planting pattern, weeding frequency and weed management aspects are crucial as an improved variety alone cannot give maximum yield [12]. The response of crops to planting pattern tended to be less in the low as compared to the high yielding environments. This can also depend on soil type, management practices like seedbed conditions and soil moisture, sowing depth, sowing date, fungicide dressings of seeds, presence of weeds and seasonal rainfall [13]. Optimum planting pattern depends on the size and nature of the crop. Planting pattern should be adopted in such a manner that minimum space is left at the disposal of weeds so that they cannot grow in a normal phase. Closely spaced crop provided good smothering potential on weed growth and development due to less availability of space for growth and development, and also well distribution of seedlings per unit area. Thus, weeds can be controlled by using appropriate planting pattern and frequency of weeding.

There is no simple method to controlling weeds of all forms: different kinds of social, economic and environmental factors influence the choice of control method to be used. Although conventional methods, like hand weeding and herbicide application are effective in weed control, they are uneconomical due to higher cost of labor and hazardous effects of the herbicides to the environment [14].

Thus, this study was conducted to evaluate the effect of planting pattern and frequency of weeding on weeds, nodulation, yield components and yield of cowpea.

\section{Materials and Methods}

\subsection{Description of the Study Area}

The experiment was conducted at Sirinka Agricultural Research Center experimental sites at Jari $\left(11^{\circ} 21^{\prime} \mathrm{N}\right.$ latitude and $39^{\circ} 38^{\prime}$ E longitude; $1680 \mathrm{~m}$. a. s. 1. altitude) and Sirinka

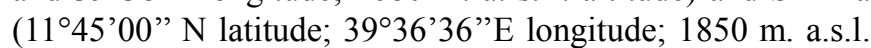
altitude) in northern Ethiopia in the 2014 main cropping season (July to October). Soil sample preparation and analysis was done at Sirinka Agriculture Research Center. The soil of the experimental fields was clay loam and clay with the pH of 6.95 and 6.91 at Sirinka and Jari, respectively. At Sirinka, the organic carbon was $1.37 \%$, total $\mathrm{N}$ was $0.09 \%$, available $\mathrm{P}$ was $12.17 \mathrm{mg} \mathrm{kg}^{-1}$ and CEC was 53.44 $\mathrm{cmol}_{\mathrm{C}} \mathrm{kg}^{-1}$ while respective values at Jari were $1.33 \%$, $0.07 \%, 9.17 \mathrm{mg} \mathrm{kg}^{-1}$ and $33.44 \mathrm{cmol}_{\mathrm{C}} \mathrm{kg}^{-1}$ (Table 1). The total seasonal rainfall received during the 2014 cropping season was $750.4 \mathrm{~mm}$ and $589.1 \mathrm{~mm}$ at Sirinka and Jari with mean maximum and minimum temperatures of 28.6 and $14.7^{\circ} \mathrm{C}$, and 29.6 and $15.8^{\circ} \mathrm{C}$, respectively (Figure 1 ).

\begin{tabular}{ll|}
\hline Rainfall Sirinka & $\rightarrow$ Max Temp Sirinka \\
$-x-$ Min Temp Sirinka & $\rightarrow-$ Max Temp Jari
\end{tabular}

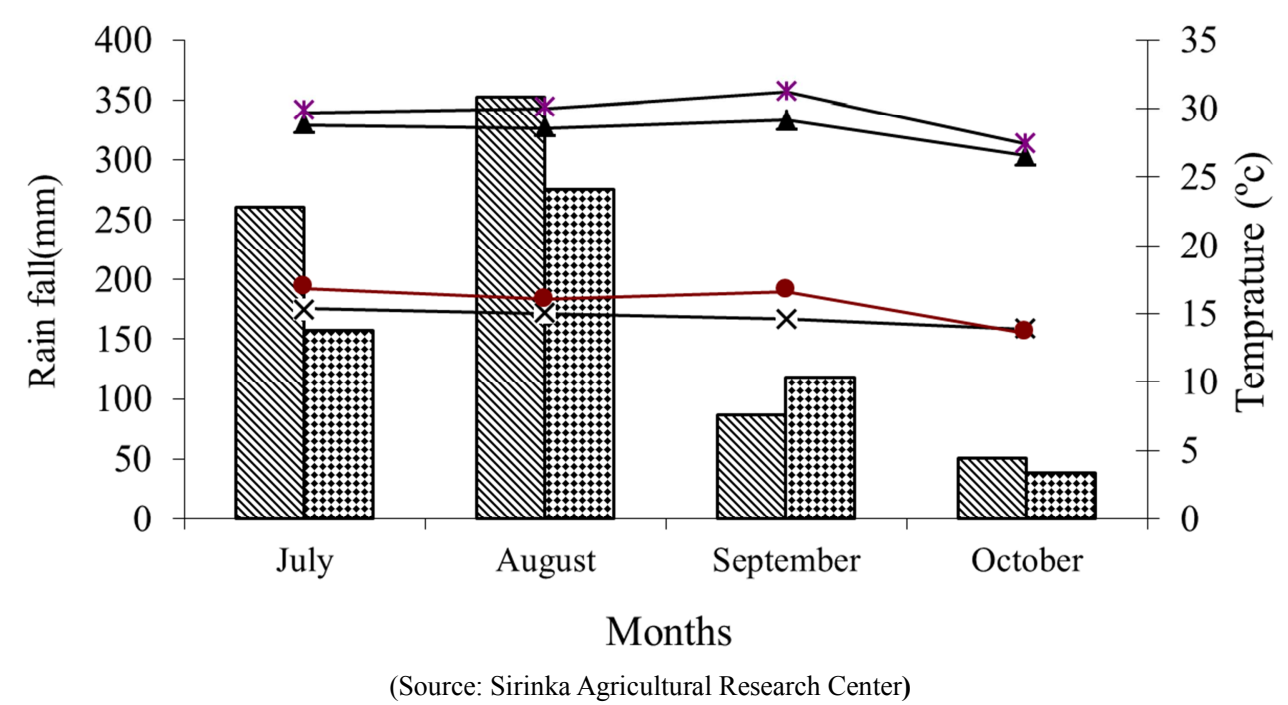

Figure 1. Monthly mean maximum and minimum temperatures $\left({ }^{\circ} \mathrm{C}\right)$ and total rainfall (mm) at Jari and Sirinka in 2014 cropping season. 


\section{Experimental Materials}

The cowpea variety Asrat (IT 92KD-279-3) released by SRARC/ARARI in 2001 was used in these experiments. The variety adapts well in moisture stress areas in the North East of Wollo and similar low land areas. This variety is suitable for an altitude range of 1450-1850 m.a.s.l. and rainfall of $660-1025 \mathrm{~mm}$. It is bush and trailing type I. It attains maturity in 95-100 days.

\subsection{Treatments and Experimental Design}

There were 18 treatments comprising combination of three planting patterns viz. $60 \mathrm{~cm} \times 10 \mathrm{~cm}(\mathrm{~S} 1), 45 \mathrm{~cm} \times 15 \mathrm{~cm}$ (S2), $45 \mathrm{~cm} \mathrm{x} 10 \mathrm{~cm}$ (S3) and six weeding frequencies; one hand weeding and hoeing at 2 weeks after crop emergence (WAE), one hand weeding and hoeing at $3 \mathrm{WAE}$, one hand weeding and hoeing at $4 \mathrm{WAE}$, two hand weeding and hoeing at 2 and 5 WAE, weed free check and weedy check. The treatments were arranged in factorial combination in randomized complete block design with three replications.

\subsection{Experimental Procedure and Management}

The experimental field was ploughed to get a fine seedbed using tractor and the plots were leveled manually. The plot size was $3.6 \mathrm{~m} \mathrm{x} 2.4 \mathrm{~m}\left(8.64 \mathrm{~m}^{-2}\right)$. The path way between replications and plots were 1.0 and $0.5 \mathrm{~m}$, respectively to facilitate movement to different plots for various operations and data recording. The treatments were assigned to each plot randomly. The cowpea variety Asrat was planted at inter- and intra- row spacing of as per the treatments on the $8^{\text {th }}$ July and $13^{\text {th }}$ July, 2014 at Jari and Sirinka, respectively. Fertilizer $\left(100 \mathrm{~kg}\right.$ DAP; $\left.18 \mathrm{~kg} \mathrm{~N}+46 \mathrm{~kg} \mathrm{P}_{2} \mathrm{O}_{5} \mathrm{ha}^{-1}\right)$ was applied uniformly to each plot at the time of planting. The outermost one row from one side and two rows from another side in plots having $60 \mathrm{~cm}$ inter row spacing while two rows from each side of the plots having $45 \mathrm{~cm}$ inter row were considered as border. From the end point of each row 3 plants in plots having $10 \mathrm{~cm}$ intra row spacing and 2 plants in $15 \mathrm{~cm}$ intra row spacing were considered as border. Thus the net plot was $1.8 \mathrm{~m} \mathrm{x} 1.8 \mathrm{~m}\left(3.24 \mathrm{~m}^{2}\right)$. The crop was harvested on October 15 and 25, 2014 at Jari and Sirinka, respectively. The harvested produce was sun dried for 7-10 days and then threshing and winnowing was done subsequently.

\subsection{Data Collection and Analysis}

Weeds

For aboveground weed dry weight, the weeds falling within the quadrat were cut near the soil surface immediately after taking observation on weed count and placed treatment wise into paper bags. The samples were sun dried for 3-4 days and thereafter were placed in an oven at $65^{\circ} \mathrm{C}$ temperatures till a constant weight and subsequently their dry weight was measured. The dry weight was expressed in $\mathrm{g} \mathrm{m}^{-2}$.

Weed Control Efficiency (WCE): It indicates the comparative magnitude of reduction in weed dry matter and was calculated as

$$
\mathrm{WCE}=\frac{W D C-W D T}{W D C} \times 100
$$

Where $\mathrm{WCE}=$ Weed Control Efficiency, WDC=Weed dry matter in weedy check, WDT $=$ Weed dry matter in a particular treatment

Crop

Plant height $(\mathrm{cm})$ was taken with a meter from 10 randomly selected and pre tagged plants in each net plot area from the base to the apex of the main stem at physiological maturity. Number of pods plant ${ }^{-1}$ was taken from the total pods of the above tagged plants at harvest. The total number of seeds from the above pods was taken and counted to average the number of seeds pod $^{-1}$. Out of these seeds, 100 seeds were counted and their weight $(\mathrm{g})$ was recorded and adjusted at $10.5 \%$ moisture content. Harvest index (\%) was determined by harvesting ten plants in each plot at physiological maturity and their dried aboveground biomass was recorded and then as grain yield divided by the aboveground dry biomass. Treatment wise per plant dry biomass weight was multiplied by the number of plants in respective treatments. This was considered as the aboveground biomass dry weight. The grain weight obtained in ten plants was added to the final yield. The grain yield $(\mathrm{kg}$ $\mathrm{ha}^{-1}$ ) was measured after threshing the sun dried plants harvested from each net plot and the yield was adjusted at $10.5 \%$ seed moisture content.

Yield loss (\%): The loss in seed yield was determined as a percentage of the difference between weeded plots (complete weed free) and yield in a particular treatment using the formula

$$
Y L=(Y 1-Y 2) / Y 1 X 100
$$

Where, $\mathrm{YL}=$ Yield loss, $\mathrm{Y} 1=$ Yield in complete weed free $(\mathrm{CWF}), \mathrm{Y} 2=$ Yield in a particular treatment

Data on weed density and weed dry biomass; crop phenology, growth, yield attributes and yield were subjected to analysis of variance using GenStat 15.0 computer software [15]. Fisher's protected Least Significant Difference (LSD) test at $5 \%$ level of significance was used to separate the differences among treatment means $(\mathrm{P}<0.05)$ [16]. As the Ftest of the error variances for the parameters of the two sites was homogeneous, combined analysis of data was used.

\section{Results and Discussion}

\subsection{Weed Parameters}

\subsubsection{Weed Dry Biomass}

\section{Weed dry biomass at first hand weeding}

The interaction of weeding frequency and planting pattern revealed that one hand weeding and hoeing at $3 \mathrm{WAE}$ along with $60 \mathrm{~cm} \times 10 \mathrm{~cm}$ planting pattern gave the lowest weed dry weight $\left(27.20 \mathrm{gm}^{-2}\right)$ which was significantly lower than all the other interactions, except the interaction of one hand weeding at $3 \mathrm{WAE}, 4 \mathrm{WAE}$, and two hand weeding at 2 and 5 
WAE under $45 \mathrm{~cm} \times 15 \mathrm{~cm}$ spacing and weedy check under all the spacings (Table 5). Thus, the results revealed no significant difference in weed dry weight between $60 \mathrm{~cm} \mathrm{x}$ $10 \mathrm{~cm}$ and $45 \mathrm{~cm} \times 10 \mathrm{~cm}$ spacing under all the weed management practices. In contrast, under weedy check no significant difference existed between $45 \mathrm{~cm}$ x $15 \mathrm{~cm}$ and 45 $\mathrm{cm} \times 10 \mathrm{~cm}$ spacing and which was significantly reduced compared to $60 \mathrm{~cm} \mathrm{x} 10 \mathrm{~cm}$ spacing. However, uncontrolled weed infestation resulted in significantly higher weed dry weight. The higher weed dry weight in weedy check might be due to higher weed density that provided an opportunity to the weeds to compete vigorously for nutrients, space, light, water and carbon dioxide resulting in higher biomass production (Table 5).

On the other hand, weed dry matter accumulation at Sirinka was significantly higher than at Jari under the influence of all the weed management practices. Moreover, among hand weeding treatments no significant difference was observed on weed dry weight at Jari, while at Sirinka delay in hand weeding (4 WAE) resulted in significant increase over early hand weedings (Table 5).

As the number of weeks after crop emergence for first hand weeding increased from one hand weeding and hoeing at 2 WAE to one hand weeding and hoeing at 4 WAE, dry weight accumulation by the weeds also increased. This could also be attributed to the potential of these treatments to control weeds beyond the critical period of cowpea growth. This implies that, late weeding results in crop losses, especially if it is carried out after the critical period of weed competition. The result of this experiment was in agreement with [17] who stated that growth of weeds during the first 40 days of crop growth reduced cowpea yields by $59 \%$. Where weeds competed for the first 10 days only, it was reduced by $6 \%$. The critical period for weed competition in cowpea was between 20 and 40 DAE [18].

Table 1. Interaction effect of location with weed management practices and planting pattern with weed management practices on total weed dry biomass ( $g$ $\left.{ }^{2}\right)$ at first weeding in 2014 cropping season.

\begin{tabular}{|c|c|c|c|c|c|}
\hline & \multicolumn{2}{|c|}{ Location (L) } & \multicolumn{3}{|c|}{ Planting pattern $(\mathbf{P})$} \\
\hline & Jari & Sirinka & S1 & $\mathbf{S 2}$ & S3 \\
\hline \multicolumn{6}{|l|}{ Weeding frequency $(\mathrm{W})$} \\
\hline One hand weeding and hoeing at 2 WAE & $48.5^{\mathrm{cd}}$ & $23.4^{\mathrm{f}}$ & $40.8^{\mathrm{d}-\mathrm{f}}$ & $34.7^{\mathrm{d}-\mathrm{f}}$ & $32.4^{\mathrm{ef}}$ \\
\hline One hand weeding and hoeing at 3 WAE & $53.8^{\mathrm{c}}$ & $20.5^{\mathrm{f}}$ & $27.2^{\mathrm{f}}$ & $45.4^{\mathrm{de}}$ & $38.9^{\mathrm{d}-\mathrm{f}}$ \\
\hline One hand weeding and hoeing at 4 WAE & $57.6^{\mathrm{bc}}$ & $38.0^{\mathrm{de}}$ & $38.5^{\mathrm{d}-\mathrm{f}}$ & $65.6^{\mathrm{bc}}$ & $39.3^{\mathrm{d}-\mathrm{f}}$ \\
\hline Two hand weeding and hoeing at 2 and 5 WAE & $52.4^{\mathrm{c}}$ & $26.7^{\mathrm{ef}}$ & $28.5^{\mathrm{f}}$ & $49.8^{\mathrm{cd}}$ & $40.3^{\mathrm{d}-\mathrm{f}}$ \\
\hline Weed free check & $0.00^{\mathrm{g}}$ & $0.00^{\mathrm{g}}$ & $0.00^{\mathrm{g}}$ & $0.00^{\mathrm{g}}$ & $0.00^{\mathrm{g}}$ \\
\hline $\mathrm{LSD}(5 \%) x \mathrm{~W} / \mathrm{P} x \mathrm{~W}$ & 13.2 & & 16.2 & & \\
\hline CV (\%) & 34.5 & & & & \\
\hline
\end{tabular}

Means in columns and rows followed by the same letter(s) are not significantly different at $5 \%$ level of significance; LSD= Least significant difference; CV= Coefficient of variation

The influence of interaction of location with weeding frequency indicated that the highest weed dry weight was observed with two hand weeding 2 and 5 WAE which was statistically at par at Jari but was significantly higher than all the weeding frequencies at Sirinka. Significantly lower weed dry weight was observed at Sirinka than at Jari under all the weeding frequencies (Table 1).

Weed dry biomass at harvest

The lowest total weed dry weight $\left(48.8 \mathrm{~g} \mathrm{~m}^{-2}\right)$ was recorded with the combination of $60 \mathrm{~cm} \times 10 \mathrm{~cm}$ planting pattern and two hand weeding and hoeing at 2 and 5 WAE at Sirinka (Table 6). However, it did not differ significantly with the combination of all planting patterns with one hand weeding done at $2 \mathrm{WAE}$ and $3 \mathrm{WAE}$, and two hand weeding done at 2 and 5 WAE as well as the interaction of one hand weeding at $4 \mathrm{WAE}$ when planted in $60 \mathrm{~cm} \times 10 \mathrm{~cm}$ and S3 at Sirinka. The variable difference in weed dry weight under different planting pattern might be due to modification of crop canopy structure which in turn reduced the light transmittance to ground to stimulate weed growth as reported by [19]. Further, a high weed density (Table 2) recorded under a particular interaction effect might have invariably contributed to high weed dry weight that could be attributed to low ground cover by cowpea canopy.

Table 2. Interaction effect of location, planting pattern and weeding frequency on weed dry weight $\left(\mathrm{g} \mathrm{m}^{-2}\right)$ at harvest in 2014 cropping season.

\begin{tabular}{|c|c|c|c|c|c|c|}
\hline \multirow{2}{*}{$\begin{array}{l}\text { Location (L) } \\
\text { Planting Pattern (P) }\end{array}$} & \multicolumn{3}{|l|}{ Jari } & \multicolumn{3}{|c|}{ Sirinka } \\
\hline & S1 & S2 & S3 & S1 & S2 & S3 \\
\hline Weeding frequency $(\mathrm{W})$ & & & & & & \\
\hline One hand weeding and hoeing at $2 \mathrm{WAE}$ & $539.3^{\mathrm{e}}$ & $537.4^{\mathrm{e}}$ & $564.9^{\mathrm{d}}$ & $64.5^{1-\mathrm{o}}$ & $67.6^{\mathrm{m}-\mathrm{o}}$ & $67.1-^{\circ}$ \\
\hline One hand weeding and hoeing at $3 \mathrm{WAE}$ & $509.0^{\mathrm{g}}$ & $512.2^{\mathrm{fg}}$ & $530.1^{\mathrm{ef}}$ & $49.5^{\text {no }}$ & $61.7^{\mathrm{m}-\mathrm{o}}$ & $67.0^{1-0}$ \\
\hline One hand weeding and hoeing at $4 \mathrm{WAE}$ & $458.0^{\mathrm{i}}$ & $474.5^{\mathrm{hi}}$ & $567.1^{\mathrm{d}}$ & $66.0^{1-o}$ & $68.8^{1-n}$ & $64.8^{1-0}$ \\
\hline Two hand weeding and hoeing at 2 and 5 WAE & $488.5^{\mathrm{h}}$ & $492.8^{\mathrm{gh}}$ & $426.7^{\mathrm{j}}$ & $48.8^{\circ}$ & $59.1^{\mathrm{m}-\mathrm{o}}$ & $66.9^{1-0}$ \\
\hline Weed free check & $0.0^{\mathrm{p}}$ & $0.0^{\mathrm{p}}$ & $0.0^{\mathrm{p}}$ & $0.0^{\mathrm{p}}$ & $0.0^{\mathrm{p}}$ & $0.0^{\mathrm{p}}$ \\
\hline Weedy check & $683.7^{\mathrm{c}}$ & $738.5^{\mathrm{a}}$ & $713.2^{\mathrm{b}}$ & $83.3^{\mathrm{kl}}$ & $88.9^{\mathrm{k}}$ & $75.3^{\mathrm{k}-\mathrm{m}}$ \\
\hline LSD $(5 \%) \mathrm{L} x \mathrm{P} x \mathrm{~W}$ & 19.8 & & & & & \\
\hline CV (\%) & 4.7 & & & & & \\
\hline
\end{tabular}

Means in columns and rows followed by the same letter(s) are not significantly different at $5 \%$ level of significance 
The highest weed dry weight $\left(738.5 \mathrm{~g} \mathrm{~m}^{-2}\right)$ was recorded in the weedy check and $\mathrm{S} 2$ at Jari which was significantly higher than all the location $\mathrm{x}$ planting pattern $\mathrm{x}$ weeding frequency interactions. It was also observed that the weeds in weedy check plots accumulated higher dry weight under all the planting patterns than the other interactions at both locations. Dry weight of weeds is a better criterion of weed and crop competition. Higher dry weight of weeds reflects more utilization of soil and environmental resources. The data on weed dry weight in all weed management practices showed significant decrease as compared to weedy check (Table 2). The uninterrupted growth of the weeds might have offered severe competition to the crop thereby interfering in the utilization of various growth factors. These results are in accordance with the findings of [20] who reported decrease in weeds dry weight due to different weed management practices in mung bean.

Further, it was revealed that the weed dry weight was significantly lower at Sirinka than at Jari under all the treatments. The variation in results from location to location and year to year might often be because of environmental conditions especially soil and air temperature, along with soil moisture content and rainfall before, during and after initiation of competition. Furthermore, high infestation by late emerging $X$. strumarium at Jari seemed to increase the weed dry weight significantly. The increase in weed dry weight could also be attributed to frequent reoccurrence and persistent characteristics of weeds under Jari conditions.

\subsubsection{Weed Control Efficiency}

The highest weed control efficiency $(41.5 \%)$ was recorded with two hand weeding and hoeing at 2 and 5 WAE followed by one hand weeding and hoeing at 3 WAE $(40.4 \%)$ observed under $60 \mathrm{~cm} \times 10 \mathrm{~cm}$ spacing at Sirinka. However, these were statistically at par with the interaction of one hand weeding and hoeing at 4 WAE, and two hand weeding and hoeing at 2 and 5 weeks after crop emergence under $45 \mathrm{~cm} \mathrm{x}$ $10 \mathrm{~cm}$ and $45 \mathrm{~cm} \times 15 \mathrm{~cm}$ spacing, respectively at Jari. Therefore, at Sirinka one hand weeding done at 3 WAE or two hand weeding done at 2 and 5 WAE under $60 \mathrm{~cm} \times 10$ $\mathrm{cm}$ plant spacing, and one hand weeding at 4 WAE under 45 $\mathrm{cm} \times 10 \mathrm{~cm}$ and two hand weeding at 2 and 5 WAE under 45 $\mathrm{cm} \times 15 \mathrm{~cm}$ at Jari seemed to provide good weed control leading to higher weed control efficiency. The lowest weed control efficiency (10.9\%) was observed in $45 \mathrm{~cm} \mathrm{x} 10 \mathrm{~cm}$ spacing when one hand weeding was done each at 2 WAE and 3 WAE at Sirinka. However, it did not differ significantly with the other weeding frequencies under the same planting pattern at the same location (Table 3 ).

Higher weed control efficiency indicated better weed control thus the maximum weed control efficiency recorded in $60 \mathrm{~cm} \times 10 \mathrm{~cm}$ spacing might be due to more competition offered by cowpea for growth resources, early space covering and better light interception. Thus, low weed density and weed dry weight indicated to high weed susceptibility to the crop at Sirinka. In contrast, at Jari the closer row spacing irrespective of intra row spacing provided better weed control. However, partially this might have occurred due to significant differences in weed dry matter accumulation among the interactions of weedy check with planting pattern at Jari (Table 3).

Table 3. Interaction effect of location, planting pattern and weeding frequency on weed control efficiency (\%) in 2014 cropping season.

\begin{tabular}{|c|c|c|c|c|c|c|}
\hline Location (L) & Jari & & & Sirinka & & \\
\hline Planting Pattern (P) & S1 & $\mathbf{S 2}$ & S3 & S1 & $\mathbf{S 2}$ & S3 \\
\hline \multicolumn{7}{|l|}{ Weeding frequency $(\mathrm{W})$} \\
\hline One hand weeding and hoeing at 2 WAE & $21.1^{\mathrm{gh}}$ & $27.2^{\mathrm{d}-\mathrm{g}}$ & $20.8^{\mathrm{h}}$ & $22.4^{\mathrm{fgh}}$ & $23.5^{\mathrm{fgh}}$ & $10.9^{\mathrm{i}}$ \\
\hline One hand weeding and hoeing at 3 WAE & $25.5^{\mathrm{d}-\mathrm{f}}$ & $30.6^{\text {cde }}$ & $25.7^{\mathrm{e}-\mathrm{h}}$ & $40.4^{\mathrm{b}}$ & $30.3^{\text {cde }}$ & $10.9^{\mathrm{i}}$ \\
\hline One hand weeding and hoeing at 4 WAE & $33.0^{\mathrm{cd}}$ & $37.7^{\mathrm{cd}}$ & $20.5^{\mathrm{b}}$ & $20.6^{\mathrm{h}}$ & $22.3^{\mathrm{cd}}$ & $13.8^{\mathrm{i}}$ \\
\hline Two hand weeding and hoeing at 2 and 5 WAE & $25.5^{\mathrm{e}-\mathrm{h}}$ & $33.3^{\mathrm{bc}}$ & $40.2^{\mathrm{h}}$ & $41.5^{\mathrm{b}}$ & $33.1^{\mathrm{gh}}$ & $11.1^{\mathrm{i}}$ \\
\hline Weed free check & $100.0^{\mathrm{a}}$ & $100.0^{\mathrm{a}}$ & $100.0^{\mathrm{a}}$ & $100.0^{\mathrm{a}}$ & $100.0^{\mathrm{a}}$ & $100.0^{\mathrm{a}}$ \\
\hline Weedy check & $0.0^{\mathrm{n}}$ & $0.0^{\mathrm{n}}$ & $0.0^{\mathrm{n}}$ & $0.0^{\mathrm{n}}$ & $0.0^{\mathrm{n}}$ & $0.0^{\mathrm{n}}$ \\
\hline LSD (5\%) L $x$ P $x \mathrm{~W}$ & 6.2 & & & & & \\
\hline CV $(\%)$ & 11.3 & & & & & \\
\hline
\end{tabular}

Means in the same column and rows followed by the same letters are not significantly different at $5 \%$ level of significance

\subsection{Crop Parameters}

\subsubsection{Growth Parameters}

\section{Plant height}

The data revealed significant reduction in plant height under respective weeding frequencies at Sirinka compared to Jari. Higher plant height at Jari than at Sirinka might be attributed to differences in weather conditions especially temperature, whereby Jari had probably more conducive environmental conditions for growth and development of weeds. Under such conditions, plants might grow taller to compete for light. The observed increase in plant height in presence of severe weed interference can be due to intense competition between weeds and crop plants and their desire to get light energy. The plants at Jari attained significantly higher height in weedy check plots than all the other treatments. The lowest plant height $(54.1 \mathrm{~cm})$ was obtained with one hand weeding and hoeing at 4 WAE at Sirinka which was significantly lower than all the treatments at Jari and weedy check at Sirinka (Table 4).

This result was in line with the findings of [21] who observed that cowpea height is dependent on weed control treatments in Nigeria. Higher plant height obtained in weedy check plots at both locations might be due to the competition offered by the weeds throughout the season especially to 
light. Thus, such competition might have resulted in enhanced plant height.

Table 4. Interaction effect of location and weeding frequency on plant height (cm) of cowpea in 2014 cropping season.

\begin{tabular}{lll}
\hline & \multicolumn{2}{l}{ Location (L) } \\
\cline { 2 - 3 } & Jari & Sirinka \\
\hline Weeding frequency (W) & & \\
One hand weeding and hoeing at 2 WAE & $70.1^{\mathrm{b}}$ & $57.8^{\text {cd }}$ \\
One hand weeding and hoeing at 3 WAE & $73.4^{\mathrm{b}}$ & $56.8^{\text {cd }}$ \\
One hand weeding and hoeing at 4 WAE & $73.6^{\mathrm{b}}$ & $54.1^{\mathrm{d}}$ \\
Two hand weeding and hoeing at 2 and 5 WAE & $69.0^{\mathrm{b}}$ & $57.3^{\text {cd }}$ \\
Weed free check & $70.7^{\mathrm{b}}$ & $59.0^{\text {cd }}$ \\
Weedy check & $85.7^{\mathrm{a}}$ & $62.7^{\mathrm{c}}$ \\
LSD (5\%) L $x$ W & 6.1 & \\
CV (\%) & 9.9 & \\
\hline
\end{tabular}

Means within columns and rows having the same letter(s) are not significantly different at $5 \%$ level of significance

There was no significant effect of planting pattern on plant height which was in accord with that of [22] who also found no significant effect of plant density on plant height of cowpea. In contrast, [23] found the tallest plants from closer row spacing in cowpea. Similar results were reported by [24], [25] and [26], who indicated that the denser plant population increased the plant height due to competition among plants in faba bean. In field pea, [27] indicated that denser plant population increased plant height due to competition among plants. This might be due to close row spacing, the space for plant spreading was less and hence plant height increased significantly. On the other hand, in chickpea, [28] also observed reduction in plant height under closer row spacing. The variable results with denser population among the crops may be due to difference in canopy structure and /or the growth habit.

\subsubsection{Yield Components, Yield and Harvest Index}

Number of pods plant ${ }^{-1}$

Significantly higher number of pods plant $^{-1}$ (23.8) was recorded with the combination of $60 \mathrm{~cm} \times 10 \mathrm{~cm}$ planting pattern and weed free check at Jari than the other interactions (Table 5). It was followed by one hand weeding and hoeing at 3 WAE under $\mathrm{S} 2$ at the same location. However, this treatment was statistically in parity with that of $45 \mathrm{~cm} \times 10$ $\mathrm{cm}$ planting pattern with weed free check at Jari, and interaction of all planting patterns with weed free check as well as the interaction of two hand weeding and hoeing at 2 and 5 WAE with S2 at Sirinka. Planting pattern and weeding frequency, weed free check under all the planting patterns had no significant difference with each other at Sirinka. In general, the higher number of pods plant ${ }^{-1}$ in weed free check might be due to the absence of competition from weeds as the plots were kept weed free throughout the cropping season. The easily accessible factors (nutrient, moisture and light) for individual plant might have also helped to retain more flowers and higher net assimilation rate in the absence of competition from weeds. Planting pattern had no significant effect on number of pods when hand weeding was resorted either at $3 \mathrm{WAE}$ or $4 \mathrm{WAE}$, and, weed free check at Sirinka. However, at Jari similar results were observed with hand weeding and hoeing at $4 \mathrm{WAE}$ and complete weed free.

Also the development of more and vigorous leaves under low weed infestation might have helped to improve the photosynthetic efficiency of the crop that supported large number of pods [29]. This might have resulted in significant increase in number of pods plant ${ }^{-1}$ in some over the other interactions. Likewise, [30] stated that the number of pods produced per plant or maintained to final harvest depends on a number of environmental and management practices. Similar results were reported on chickpea by [31]; [32] and [33] where weed interference decreased number of pod plant $^{-1}$. Also other studies on mung bean indicated that with the decrease in weeds biomass number of pods plant ${ }^{-1}$ increased [34].

Table 5. Interaction effect of location, planting pattern and weeding frequency on number of pods plant ${ }^{1}$ of cowpea in 2014 cropping season.

\begin{tabular}{|c|c|c|c|c|c|c|}
\hline Location (L) & Jari & & & Sirinka & & \\
\hline Planting Pattern (P) & S1 & S2 & S3 & S1 & $\mathbf{S 2}$ & S3 \\
\hline \multicolumn{7}{|l|}{ Weeding frequency $(\mathrm{W})$} \\
\hline One hand weeding and hoeing at 2 WAE & $9.7^{\circ}$ & $17.7^{\mathrm{e}-\mathrm{h}}$ & $14.1^{\mathrm{j}-\mathrm{m}}$ & $13.4^{j-n}$ & $17.5^{\mathrm{f}-\mathrm{i}}$ & $13.3^{\mathrm{k}-\mathrm{n}}$ \\
\hline One hand weeding and hoeing at $3 \mathrm{WAE}$ & $19.2^{b-f}$ & $20.9^{\mathrm{b}}$ & $12.7^{\mathrm{lmn}}$ & $15.4^{\mathrm{h}-\mathrm{k}}$ & $15.1^{\mathrm{i}-1}$ & $13.5^{\mathrm{j}-\mathrm{n}}$ \\
\hline One hand weeding and hoeing at 4 WAE & $14.7^{\mathrm{j}-\mathrm{m}}$ & $14.6^{\mathrm{j}-\mathrm{m}}$ & $14.4^{\mathrm{j}-\mathrm{m}}$ & $15.0^{\mathrm{i}-1}$ & $13.4^{\mathrm{j}-\mathrm{n}}$ & $15.4^{\mathrm{h}-\mathrm{k}}$ \\
\hline Two hand weeding and hoeing at 2 and 5 WAE & $17.8^{\mathrm{d}-\mathrm{h}}$ & $15.9^{\mathrm{g}-\mathrm{j}}$ & $13.1^{\mathrm{k}-\mathrm{n}}$ & $17.5^{\mathrm{fi}}$ & $18.7^{\mathrm{b}-\mathrm{f}}$ & $12.3^{\mathrm{mn}}$ \\
\hline Weed free check & $23.8^{\mathrm{a}}$ & $18.3^{\mathrm{cg}}$ & $20.1^{\text {b-e }}$ & $20.6^{\mathrm{bc}}$ & $20.3^{\mathrm{bcd}}$ & $18.6^{\mathrm{b}-\mathrm{f}}$ \\
\hline $\operatorname{LSD}(5 \%) \mathrm{L} x \mathrm{P} x \mathrm{~W}$ & 2.5 & & & & & \\
\hline CV $(\%)$ & 10.3 & & & & & \\
\hline
\end{tabular}

Means in the same column and rows followed by the same letter(s) are not significantly different at $5 \%$ level of significance

Weed competition throughout the crop season resulted in lowest number of pods (5.2 pant $\left.^{-1}\right)$ when cowpea was planted in S3, which was statistically at par with weedy check under S2 at Jari. Both these interactions resulted in significant reduction in number of pods plant $^{-1}$ than the other location, planting patterns and weeding frequency interaction effects. Significantly lowest number of pods plant ${ }^{-1}$ in weedy check might be due to solar light limitation that decreased the $\mathrm{N}_{2}$ - fixation capability of the crop. In general, the increase in the number of pods plant ${ }^{-1}$ in wider row spacing might be due to vigorous plants as in wider spacing; plant grew vigorously that might produce more branches resulting in high number of pods per plant. On the other hand, in closer row spacing in this case higher density $(45 \mathrm{~cm} \times 10 \mathrm{~cm})$, the plant growth was decreased which resulted in less number of pods per plant. In line with this result, [35] reported that number of 
pods plant ${ }^{-1}$ was significantly reduced with the increase in plant densities. Similar results were reported in field pea by [23], where they, found the highest number of pods plant ${ }^{-1}$ in wider row spacing as compared to closer spacing. In soybean also the number of pods per plant increased with corresponding increase in row spacing. This increase of pods per plant in wider row spacing might be because, at wider row spacing the number of nodes and branches increased [36] providing more fruit bearing area. [37], found that with increasing plant density pods per plant decreased accordingly. [38], found that pods per plant were less at narrower row spacing and comparatively more at wider row spacing.

The results of this experiment somewhat contradicts the findings of these authors as S2 had the lowest plant density. However, the difference in results might have been governed more by planting pattern than density. Moreover, the results of above authors were based on inter row spacing rather than a combination of inter- and intra- row spacing. Furthermore, differences in soil types, weather conditions, weed species and their densities might have also bearing on yield attributes of crops.

Number of seeds pod ${ }^{-1}$

The highest number of seeds $\operatorname{pod}^{-1}$ (14.8) was obtained under weed free conditions in $45 \mathrm{~cm} \times 10 \mathrm{~cm}$ planting pattern at Sirinka, while the lowest number of seeds $\operatorname{pod}^{-1}(6.6)$ was obtained with the combination of weedy check and S2 at Jari. The lowest number of seeds pod $^{-1}$ thus obtained was statistically at par with the one obtained from weedy check and $45 \mathrm{~cm} \times 10 \mathrm{~cm}$ planting pattern at the same location (Table 6). [39] reported that the number of seeds was affected due to weed infestation. According to [40], more weed suppression provided better crop growth for more grain formation.

This difference in the number of grains might therefore be due to weed suppression which resulted in more translocation and assimilation of photosynthates towards grain formation [41]. In line with this, [42] and [43] also reported that number of seeds pod $^{-1}$ of common bean was significantly reduced with the increased weed infestation and significantly increased with the weed free period. Moreover, in complete weed free treatment, the pods were healthy and completely filled as against shriveled and few seeds in weedy check at Jari. In contrast to this result, [44] and [45] reported no significant effect of row spacing on number of seeds pod $^{-1}$ in mung bean. Also, the results of this experiment are in contrast with the results obtained by [46], who reported that plant density was negatively related to number of seed pod $^{-1}$ in faba bean.

Table 6. Interaction effect of location, planting pattern and weeding frequency on number of seeds pod ${ }^{-1}$ of cowpea in 2014 cropping season.

\begin{tabular}{|c|c|c|c|c|c|c|}
\hline \multirow{2}{*}{$\begin{array}{l}\text { Location (L) } \\
\text { Planting Pattern (P) }\end{array}$} & \multicolumn{3}{|l|}{ Jari } & \multicolumn{3}{|l|}{ Sirinka } \\
\hline & S1 & S2 & S3 & S1 & S2 & S3 \\
\hline Weeding frequency $(\mathrm{W})$ & & & & & & \\
\hline One hand weeding and hoeing at $2 \mathrm{WAE}$ & $9.6^{\mathrm{jk}}$ & $12.6^{\mathrm{c}-\mathrm{h}}$ & $11.3^{\mathrm{f}-\mathrm{j}}$ & $12.2^{\mathrm{d}-\mathrm{h}}$ & $13.3^{\mathrm{a}-\mathrm{e}}$ & $12.6^{\mathrm{b}-\mathrm{h}}$ \\
\hline One hand weeding and hoeing at $3 \mathrm{WAE}$ & $11.0^{\mathrm{g-j}}$ & $12.2^{\mathrm{d}-\mathrm{h}}$ & $12.6^{\mathrm{c}-\mathrm{h}}$ & $14.5^{\mathrm{abc}}$ & $13.5^{\mathrm{a}-\mathrm{e}}$ & $12.6^{\mathrm{b}-\mathrm{h}}$ \\
\hline One hand weeding and hoeing at $4 \mathrm{WAE}$ & $13.0^{\mathrm{a}-\mathrm{f}}$ & $11.0^{\mathrm{g}-\mathrm{j}}$ & $11.3^{\mathrm{f}-\mathrm{j}}$ & $13.2^{\mathrm{a}-\mathrm{f}}$ & $13.7^{\mathrm{a}-\mathrm{d}}$ & $13.3^{\mathrm{a}-\mathrm{e}}$ \\
\hline Two hand weeding and hoeing at 2 and $5 \mathrm{WAE}$ & $12.4^{\mathrm{d}-\mathrm{h}}$ & $12.4^{\mathrm{d}-\mathrm{h}}$ & $13.4^{\mathrm{a}-\mathrm{e}}$ & $13.8^{\mathrm{a}-\mathrm{d}}$ & $10.8^{\text {hij }}$ & $13.6^{\mathrm{a}-\mathrm{d}}$ \\
\hline Weed free check & $13.6^{\mathrm{a}-\mathrm{e}}$ & $12.8^{\mathrm{b}-\mathrm{g}}$ & $12.7^{\mathrm{b}-\mathrm{h}}$ & $14.5^{\mathrm{ab}}$ & $13.5^{\mathrm{a}-\mathrm{e}}$ & $14.8^{\mathrm{a}}$ \\
\hline Weedy check & $10.1^{\mathrm{ijk}}$ & $6.6^{1}$ & $8.2^{\mathrm{kl}}$ & $13.5^{\mathrm{a}-\mathrm{e}}$ & $13.6^{\mathrm{a}-\mathrm{e}}$ & $11.7^{\mathrm{e}-\mathrm{i}}$ \\
\hline $\operatorname{LSD}(5 \%) \mathrm{L} x \mathrm{P} x \mathrm{~W}$ & 1.9 & & & & & \\
\hline CV $(\%)$ & 9.7 & & & & & \\
\hline
\end{tabular}

Means in the same columns and rows followed by the same letters are not significantly different at $5 \%$ level of significance

The number of seeds pod ${ }^{-1}$ in general was more at Sirinka than at Jari. This difference might be ascribed to the differences in environmental conditions that prevailed at the two locations resulting in prolonged grain filling period that was 33 days at Sirinka as against 25 days at Jari. Moreover, significantly lower weed density at Sirinka than at Jari might have resulted in interception of more sunlight for enhanced photo assimilation thus supporting more number of seeds pod $^{-1}$.

\section{Hundred seed weight}

The uppermost 100 seed weight $(13.9 \mathrm{~g})$ was obtained under weed free environment at Sirinka which was statistically at par with one hand weeding either at 3 WAE or $4 \mathrm{WAE}$ at the same location. Similar findings were reported by [47] and [48] where row spacing exhibited no significant difference between different treatment combinations in soybean. Hundred seed weight as a result of these treatments was significantly higher than all the weeding frequency treatments at Jari. The plants under complete weed free environment were free from weed competition that might have enhanced the availability of nutrients and better translocation of photosynthates from source to sink resulting in higher accumulation of photosynthates in the seeds.

Table 7. Interaction effect of location and weeding frequency on hundred seed weight ( $g$ ) of cowpea in 2014 cropping season.

\begin{tabular}{lll}
\hline & \multicolumn{2}{l}{ Location (L) } \\
\hline & Jari & Sirinka \\
\hline Weeding frequency (W) & & \\
One hand weeding and hoeing at 2 WAE & $12.4^{\mathrm{de}}$ & $13.1^{\mathrm{bc}}$ \\
One hand weeding and hoeing at 3 WAE & $12.1^{\mathrm{ef}}$ & $13.8^{\mathrm{a}}$ \\
One hand weeding and hoeing at 4 WAE & $11.7^{\mathrm{fg}}$ & $13.5^{\mathrm{ab}}$ \\
Two hand weeding and hoeing at 2 and 5 WAE & $12.1^{\mathrm{ef}}$ & $13.1^{\mathrm{bc}}$ \\
Weed free check & $12.7^{\mathrm{cd}}$ & $13.9^{\mathrm{a}}$ \\
Weedy check & $11.1^{\mathrm{h}}$ & $11.5^{\mathrm{gh}}$ \\
LSD (5\%) L $x$ W & 0.5 & \\
CV (\%) & 4.2 & \\
\hline
\end{tabular}

Means in the column and rows followed by the same letters are not significantly different at $5 \%$ level of significance 
These results were in line with the previous research conducted by [49] who found that 100 seed weight was increased with reduced weed infestation in mung bean. Similar results were reported on chickpea by [50], [31], [32] and [33] where weed interference decreased simultaneously number of pods plant ${ }^{-1}$ and 100 seed weight. Further, it was found that except weedy check under all the weeding frequencies, the hundred seed weight was significantly higher at Sirinka than at Jari (Table 7).

\section{Grain yield}

The greatest grain yield (4508 $\mathrm{kg} \mathrm{ha}^{-1}$ ) was obtained as a result of interaction of complete weed free under $60 \mathrm{~cm} \mathrm{x}$ $10 \mathrm{~cm}$ planting pattern at Sirinka which was statistically at par with the yield obtained in complete weed free under 45 $\mathrm{cm} \times 15 \mathrm{~cm}$ and $45 \mathrm{~cm} \times 10 \mathrm{~cm}$ planting patterns at the same location and $60 \mathrm{~cm} \times 10 \mathrm{~cm}$ planting pattern at Jari. The results also demonstrated that there was no significant difference in yield due to planting pattern at Sirinka as well as at Jari when the crop was raised under weed free environment. Similarly, [51] observed no effect of row spacing on white bean and soybean yield when crops were grown under weed free environments, while others observed a positive yield response under narrower spacing ([52]; [53].

The yield obtained at Sirinka under the influence of weed free check and $45 \mathrm{~cm}$ x $15 \mathrm{~cm}$ interaction was statistically at par with one hand weeding at $3 \mathrm{WAE}$, and two hand weeding at 2 and 5 WAE under $60 \mathrm{~cm} \times 10 \mathrm{~cm}$ planting pattern at the same location. This could be attributed to the combined ability of planting pattern and hand weeding done at a particular crop stage to control weed beyond the critical period of cowpea growth. Further, the results depicted that with one hand weeding done at $2 \mathrm{WAE}$ and $3 \mathrm{WAE}$, the grain yield was significantly higher at Sirinka than at Jari under respective planting patterns (Table 7). Similar trend was also noticed under weedy check. Significantly higher weed density and dry weight at Jari than at Sirinka might have contributed to severe weed competition resulting in significant reduction in yield (Table 8).

Reduced crop weed competition due to effective weed control by various treatments resulted in its better growth and development. This can be ascribed to the fact that the effective control of weeds led to the favorable environment for growth and photosynthetic activity of the crop. Therefore, higher number of pods plant ${ }^{-1}$ (Table 5), seeds pod ${ }^{-1}$ (Table 6) and 100 seed weight (Tables 7) might have contributed to the significantly higher grain yield in these treatments. Similar results were obtained by many workers [54]; [55] and [56] where they reported that the impact of weeds on yields of crops varied with the characteristics of crop, the weed species, weed density, the environment, and the stage of crop growth and duration of crop exposure to weeds.

Table 8. Interaction effect of location, planting pattern and weeding frequency on grain yield ( $\mathrm{kg} \mathrm{ha}^{-1}$ ) of cowpea in 2014 cropping season.

\begin{tabular}{|c|c|c|c|c|c|c|}
\hline Location (L) & Jari & & & Sirinka & & \\
\hline Planting Pattern (P) & S1 & S2 & S3 & S1 & S2 & S3 \\
\hline \multicolumn{7}{|l|}{ Weeding frequency $(\mathrm{W})$} \\
\hline One hand weeding and hoeing at 2 WAE & $2184^{\text {no }}$ & $2318^{\mathrm{mn}}$ & $1566^{\mathrm{p}}$ & $3587^{\mathrm{c}-\mathrm{h}}$ & $3041^{i-1}$ & $3183^{\mathrm{h}-1}$ \\
\hline One hand weeding and hoeing at $4 \mathrm{WAE}$ & $3367^{\mathrm{e}-\mathrm{j}}$ & $3294^{\mathrm{f}-\mathrm{k}}$ & $1969^{n-p}$ & $3332^{\mathrm{e}-\mathrm{k}}$ & $2931^{\mathrm{j}-1}$ & $3386^{\mathrm{e}-\mathrm{j}}$ \\
\hline Two hand weeding and hoeing at 2 and 5 WAE & $3257^{\mathrm{g}-\mathrm{k}}$ & $2964^{\mathrm{jkl}}$ & $3377^{e-j}$ & $3837^{\mathrm{b}-\mathrm{e}}$ & $3756^{\mathrm{c}-\mathrm{g}}$ & $3384^{e-j}$ \\
\hline Weed free check & $3986^{\mathrm{a}-\mathrm{d}}$ & $3683^{\mathrm{c}-\mathrm{h}}$ & $3498^{\mathrm{d}-\mathrm{i}}$ & $4508^{\mathrm{a}}$ & $4285^{\mathrm{ab}}$ & $4049^{\mathrm{a}-\mathrm{c}}$ \\
\hline $\operatorname{LSD}(5 \%) \mathrm{L} x \mathrm{P} x \mathrm{~W}$ & 526.5 & & & & & \\
\hline $\mathrm{CV}(\%)$ & 11.1 & & & & & \\
\hline
\end{tabular}

Means in the same columns and rows followed by the same letters are not significantly different at $5 \%$ level of significance

The overall weed management practices and planting pattern proved effective in controlling weeds and increasing the grain yield over weedy check. The lowest grain yield in weedy check (Table 8) was as a result of intense weed competition (Table 6). In agreement with this result, [57] reported that controlling weeds and lesser competition within the plant community could result in utilization of the available resources efficiently, which in turn is reflected in higher yield. [53] also opined better translocation of photosynthates under lesser competition among plants and this could be one of the reasons for obtaining higher yields. [58] also reported higher yield of crop as a result of yield contributing characters, lesser number of weeds and better nutrient availability to the crop. These results are in agreement with [59] and [60], where low plant density produced a higher yield in faba bean. However, these results are in contrast with [25], [61] and [62], who reported high yields of faba beans at higher planting density.

\section{Aboveground dry biomass yield}

The maximum aboveground dry biomass yield (12413 kg $\mathrm{ha}^{-1}$ ) was obtained with one hand weeding and hoeing at 4 WAE at Jari which was not significantly different from one hand weeding and hoeing at 3 WAE and complete weed free at the same location, and except weedy check at Sirinka (Table 9). The weedy check at Jari resulted in the lowest aboveground dry biomass yield $\left(2089 \mathrm{~kg} \mathrm{ha}^{-1}\right)$ of crop which was significant compared to other location and weeding frequency interactions. On the other hand, while comparing the aboveground dry biomass yield at Sirinka, the weedy check also resulted in significantly lower aboveground dry biomass yield than other interactions. However, this had statistically at par yield with one hand weeding at 2 WAE at Jari. This result indicated that very early weeding at Jari may not be beneficial for increasing aboveground dry biomass of cowpea. It might be possible that the late germinating weed 
$X$. strumarium might have suppressed the crop growth more in this treatment than others.

Table 9. Interaction effect of location and weeding frequency on aboveground dry biomass yield of cowpea $\left(\mathrm{kg} \mathrm{ha}^{-1}\right)$ in 2014 cropping season.

\begin{tabular}{lll}
\hline & \multicolumn{2}{l}{ Location (L) } \\
\cline { 2 - 3 } & Jari & Sirinka \\
\hline Weeding frequency (W) & & \\
One hand weeding and hoeing at 2 WAE & $9197^{\mathrm{c}}$ & $11752^{\mathrm{ab}}$ \\
One hand weeding and hoeing at 3 WAE & $11514^{\mathrm{ab}}$ & $12099^{\mathrm{ab}}$ \\
One hand weeding and hoeing at 4 WAE & $12413^{\mathrm{a}}$ & $11334^{\mathrm{ab}}$ \\
Two hand weeding and hoeing at 2 and 5 WAE & $10843^{\mathrm{b}}$ & $11570^{\mathrm{ab}}$ \\
Weed free check & $11959^{\mathrm{ab}}$ & $11810^{\mathrm{ab}}$ \\
Weedy check & $2089^{\mathrm{d}}$ & $8134^{\mathrm{c}}$ \\
LSD (5\%) L $x$ W & 1386.1 & \\
CV (\%) & 14.2 & \\
\hline
\end{tabular}

Means in the columns and rows followed by the same letters are not significantly different at $5 \%$ level of significance

[63] reported that the increased dry biomass weight of the crop was highly governed by the length of weed free period.
However, high production of total dry matter might not necessarily be of great value when the grain comprises a part of the plant. The higher aboveground dry biomass yield at one hand weeding and hoeing at 4 WAE might be due to better condition in soil rhizosphere that improved the competitive ability of the crop and favored more vegetative growth.

\section{Harvest index}

It ranged from $18.2 \%$ in weedy check in Jari to $39.1 \%$ from weed free check at Sirinka both under $60 \mathrm{~cm} \times 10 \mathrm{~cm}$ planting pattern. The highest harvest index thus observed differed significantly with the rest of the combinations except that of weed free check with S2 at the same location. The results also demonstrated that at both the locations, the harvest index under planting patterns did not differ significantly in weedy check. Higher plant population decreased harvest index due to more dry biomass than the grain. Similar results were obtained by [64] who reported that lower plant population tended to increase harvest index in soybean.

Table 10. Interaction effect of location, planting pattern and weeding frequency on harvest index (\%) of cowpea in 2014 cropping season.

\begin{tabular}{|c|c|c|c|c|c|c|}
\hline Location (L) & Jari & & & Sirinka & & \\
\hline Planting Pattern (P) & S1 & $\mathbf{S 2}$ & S3 & S1 & $\mathbf{S 2}$ & S3 \\
\hline \multicolumn{7}{|l|}{ Weeding frequency $(\mathrm{W})$} \\
\hline One hand weeding and hoeing at 2 WAE & $21.7^{\mathrm{p}-\mathrm{r}}$ & $25.4^{1-0}$ & $20.2^{\mathrm{q}-\mathrm{s}}$ & $30.1^{\mathrm{e}-\mathrm{i}}$ & $27.5^{\mathrm{i}-1}$ & $27.7^{\mathrm{h}-1}$ \\
\hline One hand weeding and hoeing at $3 \mathrm{WAE}$ & $26.0^{\mathrm{j}-\mathrm{m}}$ & $25.7^{\mathrm{k}-\mathrm{n}}$ & $22.9^{\mathrm{n}-\mathrm{q}}$ & $31.1^{\mathrm{d}-\mathrm{g}}$ & $29.8^{\mathrm{e}-\mathrm{i}}$ & $9.7^{\mathrm{e}-\mathrm{i}}$ \\
\hline One hand weeding and hoeing at 4 WAE & $23.4^{\mathrm{m}-\mathrm{p}}$ & $28.9^{\mathrm{f}-\mathrm{j}}$ & $18.8^{\mathrm{rs}}$ & $29.1^{\mathrm{f}-\mathrm{i}}$ & $29.6^{\mathrm{e}-\mathrm{i}}$ & $27.5^{\mathrm{i}-1}$ \\
\hline Two hand weeding and hoeing at 2 and 5 WAE & $30.7^{\mathrm{d}-\mathrm{h}}$ & $31.4^{\mathrm{d}-\mathrm{f}}$ & $28.8^{\mathrm{f}-\mathrm{k}}$ & $33.7^{\text {bcd }}$ & $34.8^{\mathrm{bc}}$ & $28.1^{\mathrm{g}-\mathrm{l}}$ \\
\hline Weed free check & $31.8^{\mathrm{c}-\mathrm{f}}$ & $30.9^{\mathrm{d}-\mathrm{g}}$ & $32.2^{\mathrm{c}-\mathrm{e}}$ & $39.1^{\mathrm{a}}$ & $36.4^{\mathrm{ab}}$ & $34.7^{\mathrm{bc}}$ \\
\hline Weedy check & $18.2^{\mathrm{s}}$ & $18.2^{\mathrm{s}}$ & $18.3^{\mathrm{s}}$ & $22.5^{o-q}$ & $21.5^{\mathrm{p}-\mathrm{r}}$ & $22.3^{\mathrm{pq}}$ \\
\hline $\operatorname{LSD}(5 \%) \mathrm{L} x$ P $x \mathrm{~W}$ & 3.1 & & & & & \\
\hline CV $(\%)$ & 6.9 & & & & & \\
\hline
\end{tabular}

Means in the columns and rows followed by the same letter(s) are not significantly different at $5 \%$ level of significance

Both at Sirinka and Jari weed free check gave significantly higher harvest index compared to other weed control treatments. Harvest index varied significantly due to differences in weed control treatments. Higher harvest index implies higher partitioning of dry matter in grain and it was higher at Sirinka than at Jari. In addition, variations in environmental factors, and other cultural practices might have influenced harvest index (Table 10).

Yield Loss

The lowest yield loss (6.4\%) was recorded with two hand weeding and hoeing at 2 and 5 WAE under $45 \mathrm{~cm} \times 10 \mathrm{~cm}$ planting pattern at Jari (Table 11). However, it was statistically at par with the yield loss observed with the interaction of the other planting patterns and two hand weeding at 2 and $5 \mathrm{WAE}$, and one hand weeding at $4 \mathrm{WAE}$ under $60 \mathrm{~cm} \times 10 \mathrm{~cm}$ and S2 at Jari. Similarly, it was also at par with the combination of one hand weeding at $3 \mathrm{WAE}$, and two hand weeding at 2 and 5 WAE under all the planting patterns, and one hand weeding at 4 WAE under S3 at Sirinka (Table 11). This indicated the beneficial effect of this combination in controlling the weeds for achieving higher yield. The results revealed significantly higher (89.3-91.6\%) yield reduction in weedy checks under the different planting patterns at Jari. It was also found that the yield loss remained statistically non-significant by the main effect of planting patterns at both the locations. [56] reported that weed infestation throughout the crop life cycle resulted in about 64 to $68 \%$ reduction in potential grain yield of cowpea. [64] reported yield losses ranging between $50-86 \%$ due to unchecked weed growth throughout the life cycle in cowpea. Thus, the result showed that higher yield loss implied greater yield loss due to weed competition.

On the other hand, the yield loss obtained as a result of full season weed interference under different planting patterns at Sirinka was similar to one hand weeding at 2 WAE under 45 $\mathrm{cm} \times 10 \mathrm{~cm}$ spacing at Jari (Table 11). Thus, these results in general indicated that at Jari, to prevent yield loss one hand weeding at 4 WAE under $60 \mathrm{~cm} \times 10 \mathrm{~cm}$ and S2 and at Sirinka at 3 WAE under all the planting pattern can be resorted. 
Table 11. Interaction effect of location, planting pattern and weeding frequency on yield loss (\%) during the 2014 cropping season.

\begin{tabular}{|c|c|c|c|c|c|c|}
\hline Location (L) & Jari & & & Sirinka & & \\
\hline Planting Pattern (P) & S1 & $\mathbf{S 2}$ & S3 & S1 & $\mathbf{S 2}$ & S3 \\
\hline \multicolumn{7}{|l|}{ Weeding frequency $(\mathrm{W})$} \\
\hline One hand weeding and hoeing at 2 WAE & $45.5^{\mathrm{cd}}$ & $36.4^{\text {de }}$ & $56.5^{\mathrm{bc}}$ & $20.1^{\mathrm{f}-\mathrm{j}}$ & $29.9^{\text {efg }}$ & $21.4^{\mathrm{f}-\mathrm{j}}$ \\
\hline One hand weeding and hoeing at $3 \mathrm{WAE}$ & $27.9^{\mathrm{e}-\mathrm{h}}$ & $23.7^{\mathrm{f}-\mathrm{i}}$ & $24.4^{\mathrm{e}-\mathrm{i}}$ & $15.7^{\mathrm{h}-\mathrm{k}}$ & $13.4^{\mathrm{ijk}}$ & $18.9^{\mathrm{g}-\mathrm{k}}$ \\
\hline One hand weeding and hoeing at $4 \mathrm{WAE}$ & $16.3^{\mathrm{h}-\mathrm{k}}$ & $10.4^{\mathrm{jkl}}$ & $45.0^{\mathrm{cd}}$ & $25.7^{\mathrm{e}-\mathrm{i}}$ & $32.2^{\mathrm{ef}}$ & $16.4^{\mathrm{h}-\mathrm{k}}$ \\
\hline Two hand weeding and hoeing at 2 and 5 WAE & $18.7^{\mathrm{g}-\mathrm{k}}$ & $18.9^{\mathrm{g}-\mathrm{k}}$ & $6.4^{\mathrm{kl}}$ & $14.8^{\mathrm{ijk}}$ & $13.2^{\mathrm{ijk}}$ & $16.3^{\mathrm{h}-\mathrm{k}}$ \\
\hline Weed free check & $0.0^{1}$ & $0.0^{1}$ & $0.0^{1}$ & $0.0^{1}$ & $0.0^{1}$ & $0.0^{1}$ \\
\hline Weedy check & $89.3^{\mathrm{a}}$ & $91.6^{\mathrm{a}}$ & $89.4^{\mathrm{a}}$ & $60.7^{b}$ & $59.3^{\mathrm{b}}$ & $55.3^{\mathrm{bc}}$ \\
\hline $\operatorname{LSD}(5 \%) \mathrm{L} x \mathrm{P} x \mathrm{~W}$ & 12.5 & & & & & \\
\hline $\mathrm{CV}(\%)$ & 27.2 & & & & & \\
\hline
\end{tabular}

Means in the columns and rows followed by the same letter(s) are not significantly different at $5 \%$ level of significance; $\mathrm{S} 1=60 \mathrm{~cm} \times 10 \mathrm{~cm}$; $\mathrm{S} 2=45 \mathrm{~cm} \times 15$ $\mathrm{cm} ; \mathrm{S} 3=45 \mathrm{~cm} \times 10 \mathrm{~cm} ; \mathrm{WAE}=$ weeks after crop emergence; LSD= least significant difference; $\mathrm{CV}=$ coefficient of variation

\section{Conclusion}

The combination of $60 \mathrm{~cm} \times 10 \mathrm{~cm}$ plant spacing and two hand weeding and hoeing at 2 and 5 WAE gave lowest total weed dry weight and highest weed control efficacy at Sirinka. Weed infestation of weeds was more at Jari than at Sirinka. Number of pods per plant and seeds per pod were significantly influenced by the interaction of location, planting pattern and weeding frequency. However, 100 seed weight was significantly influenced by the interaction of location with weeding frequency. When individual locations were considered, there was no significant effect of planting patterns under different hand weeding treatments at Sirinka while at Jari variable results were obtained. Yield loss due to uncontrolled weed growth was as high as $91.6 \%$ at Jari while it was $60.7 \%$ at Sirinka in weedy check under $45 \mathrm{~cm} \times 15 \mathrm{~cm}$ and $60 \mathrm{~cm} \times 10 \mathrm{~cm}$ plant spacing, respectively. The results in general indicated that at Jari, to prevent yield loss one hand weeding at $4 \mathrm{WAE}$ under $60 \mathrm{~cm} \times 10 \mathrm{~cm}$ and S2 and at Sirinka at 3 WAE under all planting pattern can be resorted. Therefore, managing the weeds with the use of $60 \mathrm{~cm} \mathrm{x} 10 \mathrm{~cm}$ and one hand weeding and hoeing at $3 \mathrm{WAE}$ at Sirinka and one hand weeding and hoeing at $4 \mathrm{WAE}$ at Jari proved to be the most feasible practice for cowpea production in the study area.

\section{Acknowledgements}

Greatest appreciation and heartfelt gratitude are conveyed to my mother Turaye Mussa. It is your love, encouragement and support that made this work to be realized. I admires your motivation, confidence and patience to shoulder multiple and demanding responsibilities together. My deep and heartfelt appreciation extends to my daughters Milietetsega and Ankion for her lovely encouragement and patience during the years of separation. I would also like to express my sincere appreciation to Gizachew Bekele Assena for funding the publication expenses. I am grateful to the Ministry of Education, Federal Democratic Republic of Ethiopia for the financial support, Sirinka Agricultural Research Center for providing research facilities and Mizan Tepi University for permitting the author for $\mathrm{PhD}$ study.

\section{References}

[1] Timko, M. P. and Singh, B. B. 2008. Cowpea, a multifunctional legume, pp. 227-257. In: Moore, P. H., Ming, R. (Eds.), Genomics of tropical crop plants. Springer, New York.

[2] Kitch, L. W., Bottenburg, H., Wolfson, J. L. 1998. Indigenous knowledge and cowpea pest management in Sub-Saharan Africa. pp. 292-302. In: Singh, B. B., Mohan, R. D. R., Dashiell, K. E., Jackai, L. E. N. (Eds.), Advances in cowpea Research. Co-publication of International Institute of Tropical Agriculture (IITA) and Japan International Center for Agricultural Sciences (JIRCAS), Ibadan, Nigeria.

[3] Muimui, K. K. 2010. Beans Stakeholder Consultative Workshop. Common Wealth Youth Programme Africa. Lusaka.

[4] Shiringani, R. P., Shimeles, H. A. 2011. Yield response and stability among cowpea genotypes at three planting dates and test environments. African Journal of Agricultural Research, 6 (4): 3259- 3263.

[5] Sankie, L., Addo-Bediako, K. O. and Ayodele, V. 2012. Susceptibility of seven cowpea [Vigna unguiculata (L.) Walp] cultivars to cowpea beetle (Callosbruchus maculatres). Agricultural Science Research Journal, 2 (2): 65-69.

[6] Muoneke, C. O., Ndukwe, O. M., Umana, P. E., Okpara, D. A., Asawalam, D. O. 2012. Productivity of vegetables cowpea [Vigna unguiculata (L.) Walp] and maize (Zea mays L.) intercropping system as influenced by component density in a tropical zone of southeastern Nigeria. International Journal of Agricultural Research Development, 15: 835-847.

[7] Williams, M. M. 2006. Planting date influences critical period of weed control in sweet corn. Weed Science, 54: 928-933.

[8] Kavalinuskaite, D. and Bobinas, C. 2006. Determination of weed composition critical period in red bat. Agronomic Research, 4: 217-220.

[9] Anwar, S., Shah, W. A., Bakht, J. and Jabeen, U. 2004. Comparison of sorghum extracts, chemical and hand weeding management in wheat crop. Journal of Agronomy, 3 (1): 59-67.

[10] Amador-Ramirez, M. D., Wilson, R. G. and Martin, A. R. 2001. Weed control and dry bean (Phaseolus vulgaris) response to in-row cultivation, rotary hoeing and herbicides. Weed Technology, 15: 429-436. 
[11] Chikoye, D., Udensi, E. U. and Lum, A. F. 2005. Evaluation of a new formulation of atrazine and metolachlor mixture for weed control in maize in Nigeria. Crop Protection, 24: 10161020 .

[12] IAR (Institute of Agricultural Research). 1987. Development of Synthetic Varieties of Maize. Department of Field Crops Maize Progress Report for the Period 1984/1985. Addis Ababa, Ethiopia.

[13] Matthews P. W., Armstrong, E. L., Lisle, C. J., Menz, I. D., Shephard P. L. and Armstrong, B. C. 2008. The effect of faba bean plant population on yield, seed quality and plant architecture under irrigation in southern NSW. Crop Agronomy Journal of Australia, 49: 999-1008.

[14] Cheema, Z. A., Hussain, S. and Khaliq, A. 2003. Efficacy of sorgaab in combination with allelopathic water extracts and reduced rate of pendimethalin for weed control in mung bean. Journal of Plant Science, 2: 21-25.

[15] Payne, R. W., Murray, D. A., Harding, S. A., Baird, D. B. and Soutar, D. M. 2009. GenStat for windows $\left(12^{\text {nd }}\right.$ edn.) Introduction. VSN International, Hemel, Hempstead.

[16] Gomez, K. A. and Gomez, A. A. 1984. Statistical Procedures for Agricultural Research. pp. 680. $2^{\text {nd }}$ Edition. John Willey and Sons, Inc.

[17] Acosta, M. 1991. Determination of the critical period of competition of weeds in cowpea bean [Vigna unguiculata (L.) Walp] in Alanje. Scientific Journal of Philippines, 5: 43-48.

[18] Muhammad, N. and Ahmad, S. 1999. Critical period of weed competition with the growth of mungbean. Pakistan Journal of Biological Science, 2 (4): 1600-1610.

[19] Weiner, J., Griepentrog, H. W. and Kristensen, L. 2001. Suppression of weeds by spring wheat Triticum aestivum increases with crop density and spatial uniformity. Journal of Applied Ecology, 38: 784-790.

[20] Naeem, M., Saeed, A. and Hakoomat, A. 2000. Efficacy of faluazifop butyl (Fusillade 25 EC) and fenoxaprop-P- ethyl (Pumas 69 EW) for weed control in mung bean. Pakistan Journal Agricultural Science, 37: 1-2.

[21] Kelechukwu, N. E, Adewale, M. O. and Ezekiel, A. A. 2007. Aluminum Influence on Performance of some Cowpea cowpea [Vigna unguiculata (L.) Walp] Varieties on a Nigerian Alfisol. Word Journal of Agricultural Science, 3 (4): 512-522.

[22] Mohamed, L. Z. 2002. The effect of intra-row spacing and starter nitrogen fertilizer on growth and yield of cowpea [Vigna unguiculata (L.) Walp]. M.Sc thesis, University of Khartoum, Sudan.

[23] Yayeh Bitew, Fekremariam Asargew, Oumer Beshir. 2014. Effect of Plant Spacing on the Yield and Yield Component of Field Pea (Pisum Sativum L.) at Adet, North Western Ethiopia. Agriculture, Forestry and Fisheries, 3 (5): 368-373.

[24] Turk, M. A. and Tawaha, A. R. M. 2002. Impact of seeding rate, sedding date, rate and method of phosphorus application in faba bean (Vicia faba L. Minpr) in the absence of moisture stress. Biotechnology and Agronomy Society of Environment, 6 (3): 171-178

[25] Khalil, S. K., Wahab, A., Rehman, A., Muhammad, F., Wahab, S., Khan, A. Z., Zubair, M., Shah, M. K., Khalil, I. H. and Amin, R. 2010. Density and planting date influence on phenological development assimilate partitioning and dry matter production of faba bean. Pakistan Journal of Botany, 42 (6): 3831- 3838.

[26] Thalji, T. 2010. Effect of plant density on seed yield and agronomic characters of faba bean (Vicia faba L.) under greenhouse conditions. Biosciences Research, 7 (1): 22-25.

[27] Derya, O. Y. 2013. Impact of plant density on yield and yield components of pea (Pisum sativum ssp. sativum L.) cultivars. Journal of Agricultural and Biological Science, 2 (8): 169174.

[28] Yousaf, A., Ahsanui, M., Tahir, G. and Ahmed, N. 1999. Effect of Inter and Intra row Spacing on Yield and Yield components of Chickpea. Pakistan Journal of Biological Science, 2 (2): 305-307.

[29] Hodgson, G. L. and Blackman, G. E. 2005. An Analysis of the Influence of Plant Density on the Growth of Vicia faba. Journal of Experimental Botany, 48: 147-165.

[30] Ayaz, S., McNeil, D. L., McKenzie, B. A. and Hill, G. D. 2001. Density and sowing depth effects on yield components of grain legumes. Proceeding of Agronomy Society, New Zealand, 29: 9-15.

[31] Rashid, A., Khan, R., Marwat, S. 2009. Importance of weed control in chickpea under rain fed condition. AmericanEurasian Journal of Agriculture and Environment Science, 5 (4): 456-459.

[32] Fathi, A. O. E., Khalaf, A. S. and Salim, N. M. 2011. Influence of tillage and weed management methods on chickpea yield and yield components, Pakistan Journal of Weed Science, 16 (2): 189-198.

[33] Tepe, I., Erman, M., Yergin, R. and Bukun, B. 2011. Critical period of weed control in chickpea under non-irrigated conditions. Turk Journal of Agriculture and Forestry, 35: 525-534.

[34] Khan, F. S., Zammurad, I. A., Muhammad, A. and Hussain, S. 2008. Response of mungbean genotypes to rhizobium inoculum and varying levels of nitrogen fertilizer. Pakistan Journal of Agricultural Research, 21: 1-4.

[35] Biswan, D. K., Haque, M. M., Hamid, A., Ahmed, J. U. and Rahman, M. A. 2002. Influence of plant population density on growth and yield of two black gram varieties. Pakistan Journal of Agronomy, 3: 83-85.

[36] Tunio, S. D., Rajput, M. J., Rajput, M. A. and Rajput, F. K. 1980. Effect of different row and plant spacings on growth and yield in soybean (Glycine max L. Merril). Egyptian Journal of Agronomy, 5 (1): 57-65.

[37] Paul, T. and Joshi, M. C. 1977. Note on response of soybean variety 'Bragg' to plant population and planting geometry in Kumaon hills. Pantnagar Journal of Research, 2 (2): 225-226.

[38] Lehman, W. F. and Lambert, J. W. 1960. Effects of spacing of soybean plants between and within rows on yield and its components. Agronomy Journal, 52 (1): 210-237.

[39] Tessema, T. and Tanner, D. G. 1997. Grass weed competition and calculated economic threshold densities in bread wheat in Ethiopia. African Crop Science Journal, 5: 371-384.

[40] Raklia, D. 1999. Efficacy of Sorghum allelopathy as weed control strategy. Kasetsart Journal of Natural Science, 40: $195-200$. 
[41] Borras, L., Slafer, G. A. and Otegui, M. E. 2004. Seed dry weight response to source-sink manipulations in wheat, maize and soybean: a quantitative reappraisal. Field Crops Research, 86: $131-146$.

[42] Tenaw Workayehu, Beyenesh Zemicchael and Waga Mazengia. 1997. Effect of variety, seed rate and weeding frequencies on weed infestation and grain yield of haricot bean. 61pp. In: Proceeding of the $2^{\text {th }}$ and $3^{\text {th }}$ Annual Conference of the Ethiopian Weed Science Society, Addis Ababa, Ethiopia.

[43] Sharma G. D., Sharma, J. J. and Sood, S. 2004. Evaluation of alachlor, metolachlor and pendimethalin for weed control in rajmash (Phaseolus vulgaris L.) in cold desert of North Western Himalayas. Indian Journal of Weed Science, 36: 287289.

[44] Shahidullah, M. and Hossain, M. M. 1987. Influence of interand intra-row spacing of soybean on yield and its components. Bangladesh Journal of Science, 22: 1-7.

[45] Ihsanullah, F., Hayat, T., Habib, A., Abdul, B. and Noor, U. 2002. Effect of Row Spacing on Agronomic Traits and Yield of Mungbean [Vigna radiata (L.) Wilczek]. Asian Journal of Plant Science, 1: 328-329.

[46] Turk, M. A., Tawaha, A. M. and El-Shatnawi, M. K. J. 2003. Response of lentil (Lens culinaris Medik.) to plant density, sowing date, phosphorus fertilization and ethephon application in the absence of moisture stress. Journal of Agronomy and Crop Science, 189: 1-6.

[47] Vrataric, M., Krizmanic, M. and Madjar, S. 1976. Effects of plant spacing and sowing on yield characteristics in new selections or genotypes of soybean. Field Crop Abstracts, 31 (11): $721-723$.

[48] Green, D. S., Burlamagui, P. F. and Shible, R. 1977. Performance of randomly selected soybean lines with semi determinate and indeterminate growth habits. Journal of Crop Science, 17 (2): 335-339.

[49] Cheema, M. and Akther, S. 2005. Efficacy of different post emergence herbicides and their application methods in controlling weeds in wheat. Pakistan Journal of Weed Science Research, 11: 23-30.

[50] Al-Thahabi, S. A., Yasin, J. Z., Abu-Irmaileh, B. E., Haddad, N. I. and Saxena, M. C. 1994. Effect of weed removal on productivity of chickpea and lentil in a Mediterranean environment. Journal of Agronomy and Crop Science, 5: 333341 .

[51] Nuland, D. S. 1989. A visual description of the common bean plant four major growth periods. Bean Improvement Cooperative, 32; 16-17.

[52] Goulden, D. S. 1976. Effect of plant population and row spacing on yield and components of yield in navy bean (Phaseolus vulgaris). New Zeland Journal of Experimental Agriculture, 4: 177-180.
[53] Grafton, K. F., Schneiter, A. A. and Nagle, B. J. 1988. Row spacing, plant population and genotype $\mathrm{x}$ row spacing interaction effects on yield and yield components of dry bean. Agronomy Journal, 80: 631-634.

[54] Ball, R. A., McNew, R. W., Vories, E. D., Keisling, T. C. and Purcell, L. C. 2001. Path analyses of population density effects on short season soybean yield. Agronomy Journal, 93 (1): 187-195.

[55] Hamad, M. S. 2010. Effect of Plant density and Cultivar on Growth and Yield of Cowpea [Vigna unguiculata (L.) Walp]. Australian Journal of Basic and Applied Science, 4 (8): 31483153.

[56] Joseph, A., Osipitan, A. O., Segun, T. L., Raphael, O. A. and Stephen, O. A. 2014. Growth and Yield Performance of Cowpea cowpea [Vigna unguiculata (L.) Walp] as influenced by Row Spacing and Period of Weed interference in South West Nigeria. Journal of Agricultural Science, 4: 16-37.

[57] Askew, S. D., Wilcut, J. W. and Cranmer, J. R. 2002. Cotton (Gossypium hirsutum L.) and weed response to flumioxazin applied pre plant and post emergence directed. Weed Technology, 16: 184-190.

[58] Vesterager, J. M., Nielsen, N. E and Hogh-Jensen, H. 2006. Variation in phosphorus uptake and use efficiencies between pigeon pea genotypes and cowpea. Journal of Plant Nutrition, 29: $1869-1888$

[59] Al-Rifaee, M., Turk, M. A. and Tawaha, A. R. M. 2004. Effect of seed size and plant population density on yield and yield components of faba bean (Vicia faba L.). International Journal of Agriculture and Biology, 2: 294-299.

[60] Thalji, T. 2006. Impact of row spacing on faba bean growth under Mediterranean rainfed conditions. Journal of Agronomy, 5 (3): 527-532.

[61] Khalil, S. K., Amanullah, A. W. and Khan, A. Z. 2011. Variation in leaf traits, yield and yield components of faba bean in response to planting dates and densities. Egypt Academic Journal of Biological Science, 2 (1): 35-43.

[62] Dahmardeh, M., Ramroodi, M. and Valizadeh, J. 2010. Effect of plant density and cultivars on growth, yield and yield components of faba bean (Vicia faba L.). African Journal of Biotechnology, 9 (50): 8643-8647.

[63] Mizan, A., Sharma, J. J. and Gebremedhin, W. 2009. Estimation of Critical Period of Weed-Crop Competition and yield Loss in Sesame (Sesamum indicum L.). Ethiopian Journal of Weed Management, 3 (1): 39-53.

[64] Weber, C. R., Shibles, R. M. and Byth, D. E. 1966. Effect of plant population and row spacing on Soybean development and production. American Society of Agronomy Journal, 58: 99-102.

[65] Li, R., Guidong, Z., Yumei, Z. and Zhanzhi, X. 2004. Damage loss and control technology of weeds in cow pea field. Weed Science, 2: 25-36. 